\title{
Characterization of a non-occluded baculovirus-like agent pathogenic to penaeid shrimp
}

\author{
E. Cesar B. Nadala Jr *, Lourdes M. Tapay, Philip C. Loh \\ Department of Microbiology, University of Hawaii, Honolulu, Hawaii 96822, USA
}

\begin{abstract}
A non-occluded baculovirus-like agent recently isolated by this laboratory from moribund Penaeus japonicus shrimps obtained from China and named Chinese baculovirus (CBV) was purified and some of its properties characterized. Under the electron microscope, negatively stained virus particles were rod-shaped, enveloped, and measured 322 to $378 \mathrm{~nm}$ in length and 130 to $159 \mathrm{~nm}$ in diameter. The nucleoprotein core exhibited a unique striated structure and measured 316 to $350 \mathrm{~nm}$ in length and 65 to $66 \mathrm{~nm}$ in diameter. The striations appear to be the result of the stacking of ring-like structures. These rings consisted of 2 rows of 12 to 14 globular subunits. Each globular subunit measured approximately $10 \mathrm{~nm}$ in diameter. SDS-PAGE gels of purified virus preparations showed, among several, 4 prominent protein bands with approximate molecular weights of $19,23.5,27.5$ and $75 \mathrm{kDa}$. The structural viral proteins were identified by western blot analysis using polyclonal hyperimmune serum made against purified CBV. The $19,27.5$, and $75 \mathrm{kDa}$ structural proteins were determined to be non-glycosylated components associated with the viral envelope. The $23.5 \mathrm{kDa}$ protein, also nonglycosylated, was identified with the capsid structure. Viral genomic DNA digested with Hind III restriction endonuclease revealed at least 29 different fragments with a conservatively estimated total size of at least $183 \mathrm{~kb}$.
\end{abstract}

KEY WORDS: Chinese baculovirus - Baculovirus - Penaeid shrimp

\section{INTRODUCTION}

A baculovirus-like agent was recently isolated by this laboratory from moribund pink shrimp Penaeus japonicus obtained from a shrimp farm in China. The isolate, labeled Chinese baculovirus (CBV), was found to cause $100 \%$ cumulative mortality 3 to $4 \mathrm{~d}$ postinfection in experimentally infected adult $P$. stylirostris (blue shrimp) and $P$. vannamei (white shrimp), the 2 principal species of penaeid shrimp cultured in Hawaii and the Western Hemisphere (Tapay et al. 1997, Lu et al. 1997). Non-occluded baculovirus-like agents that closely resemble CBV have also been reported to infect P. monodon in Thailand (Wongteerasupaya et al. 1995), $P$. monodon, $P$. japonicus and $P$. penicillatus in Taiwan (Chou et al. 1995) and P. japonicus in Japan (Inouye et al. 1994, Takahashi et al. 1994, Inouye et al. 1996). These viruses have been implicated in massive disease outbreaks and mortalities among penaeid

•E-mail: elpido@hawaii.edu shrimp. Further characterization of the different isolates will help us to better understand these viruses and their relationships to each other.

In this paper the propagation, purification, and characterization of some of the properties of CBV are described. This virus represents a potential threat to shrimp farming, particularly broodstocks in Hawaii, because of the highly lethal nature of the infection, its wide species range, and increasing geographical distribution.

\section{MATERIALS AND METHODS}

Virus propagation. The virus was propagated in white shrimp (50 to $60 \mathrm{~g}$ Penaeus vannamei) by intramuscular injection of filtrates $[200 \mu$ l of a $4 \% \mathrm{w} / \mathrm{v}$ homogenate in TNE $(0.05 \mathrm{M}$ Tris, $0.1 \mathrm{M} \mathrm{NaCl}, 1 \mathrm{mM}$ EDTA), clarified at $2000 \times g$ for $20 \mathrm{~min}$, and filtered through a $0.45 \mu \mathrm{m}$ filter] prepared from CBV-infected shrimp gill tissue. Two to four days after injection. 
hemolymph was collected from moribund specimens (by ablation of the telson and uropod), mixed with an equal volume of $20 \%(\mathrm{w} / \mathrm{v})$ sodium citrate, and stored at $-20^{\circ} \mathrm{C}$.

Virus purification. To purify the virus, various tissues were harvested from frozen infected shrimps. The tissues were suspended in TNE at $10 \% \mathrm{w} / \mathrm{v}$ and homogenized [Brinkmann Polytron 3000 (Kinematica AG) with 90/Polytron PT-DA 3012/2TS] (Brinkmann Instruments Inc., NY, USA). Tissue debris was pelleted at $2500 \times g$ for $15 \mathrm{~min}$ and the supernate further clarified by centrifugation at $4946 \times g$ for $10 \mathrm{~min}$. Virus was pelleted at $58200 \times g$ for $30 \mathrm{~min}$, resuspended in 30:1 volume of TNE (i.e. 30 parts of original volume to 1 part of new suspension), layered on top of a $20-60 \%(\mathrm{w} / \mathrm{v})$ continuous sucrose gradient, and centrifuged at 58200 $\times g$ for $2 \mathrm{~h}$. The diffuse virus band was collected by side puncture, diluted 1:5 in TNE, and pelleted at $58200 \times g$ for $30 \mathrm{~min}$. The virus pellet was resuspended in $0.5 \mathrm{ml}$ of TNE, layered on top of a 30 to $50 \%(w / v)$ continuous $\mathrm{CsCl}$ gradient and centrifuged at $192000 \times \mathrm{g}$ for $19 \mathrm{~h}$ at $4^{\circ} \mathrm{C}$. The bands of complete virions and nucleoprotein cores were collected, diluted 1:5 in TNE, and pelleted at $192000 \times g$ for $15 \mathrm{~min}$ at $4^{\circ} \mathrm{C}$. The pellets were resuspended in $0.5 \mathrm{ml} \mathrm{TNE}$ and checked for purity under the electron microscope (EM).

Electron microscopy. For EM examination, virus samples were mounted on formvar-coated, carbonstabilized copper grids (200 mesh), negatively stained with $2 \%(\mathrm{w} / \mathrm{v})$ uranyl acetate, and examined under a Zeiss EM10/A electron microscope.

SDS-PAGE. The structural proteins of the virus were analyzed by $12.5 \%$ SDS-PAGE (sodium dodecyl sulfate-polyacrylamide gel electrophoresis) according to the method of Laemmli (1970). Samples were electrophoresed for $40 \mathrm{~min}$ at $200 \mathrm{~V}$ and the gels stained using the silver stain plus kit (Biorad, CA, USA).

Preparation of antibodies. Polyclonal hyperimmune serum against CBV was prepared in New Zealand white rabbits according to the following immunization schedule: $52 \mu \mathrm{g}$ of CBV proteins in Freund's complete adjuvant were injected intradermally and subcutaneously on Day 0 . Subsequent booster injections of $52 \mu \mathrm{g} \mathrm{CBV}$ protein in Freund's incomplete adjuvant were given on Days 13,27, and 41 . The rabbits were exsanguinated on Day 63. Immunoglobulin $G$ was purified from rabbit antisera using recombinant bacterial protein-G columns (Gamma-Bind G, Genex Corp., Gaithersburg, MD, USA) and adsorbed to normal shrimp hemolymph proteins to remove cross-reacting antibodies.

Western blotting. For western blotting, purified CBV virions were electrophoresed on $12.5 \%$ SDS-PAGE gel at $200 \mathrm{~V}$ for $40 \mathrm{~min}$ and blotted onto nitrocellulose membranes (Schleicher and Schuell, NH, USA) at $100 \mathrm{~V}$ for $40 \mathrm{~min}$. The nitrocellulose (NC) membranes were then washed with $\mathrm{PBS}\left(137 \mathrm{mM} \mathrm{NaCl}, 1.4 \mathrm{mM} \mathrm{KH}_{2} \mathrm{PO}_{4}\right.$ $4.3 \mathrm{mM} \mathrm{Na} 2 \mathrm{HPO}_{4} \cdot 7 \mathrm{H}_{2} \mathrm{O}$ and $2.7 \mathrm{mM} \mathrm{KCl}$, blocked with $5 \%$ skim milk/PBS for $1 \mathrm{~h}$, washed with PBS, and then treated with 1:1000 rabbit anti-CBV IgG diluted in $1 \%$ skim milk/PBS for $1 \mathrm{~h}$. The NC paper was washed with PBST (0.05\% Tween-20/PBS) twice and once with PBS. The NC paper was then treated with 1:2500 goat anti-rabbit HRPO (horseradish peroxidase) (Kirkegaard and Perry Laboratories, MD, USA) diluted in $1 \%$ skim milk/PBS for $1 \mathrm{~h}$. The NC paper was washed $3 \times$ with PBST and then incubated with the TMB (3, 3', 5, 5'-tetramethylbenzidine; Kirkegaard and Perry Laboratories, MD, USA) substrate. All incubations were done at room temperature.

Triton and DNAse I treatment. The locations of the different viral structural proteins were analyzed by treatment of the complete virions with $1 \%$ Triton $\mathrm{X}$ 100/TNE for $1 \mathrm{~h}$ at $37^{\circ} \mathrm{C}$, and treatment of the nucleoprotein core with DNAse I ( 1 unit per $10^{9}$ particles) for $1 \mathrm{~h}$ at $37^{\circ} \mathrm{C}$. Triton-treated samples were centrifuged at $140000 \times g$ for 5 min in a Beckman Airfuge (Beckman Instruments, CA, USA) to pellet the virus particles and separate it from components that were dissolved in Triton. All samples were separated by SDS-PAGE gel electrophoresis and visualized by either silver staining or western blotting.

Glycoprotein detection. Carbohydrate moieties of purified CBV proteins western blotted onto nitrocellulose membrane were labeled using the ECL (enhanced chemiluminescence) glycoprotein detection system (Amersham Corp., IL, USA). A parallel western blot was also done using anti-CBV IgG (1:1000 dilution) to confirm the presence of all the CBV proteins.

Preparation of viral nucleic acid. The CBV DNA was purified from $\mathrm{CsCl}$ banded virus using the QIAamp Tissue Kit (QIAGEN Inc., CA, USA). Aliquots of the DNA (200 ng in $17 \mu \mathrm{l}$ ) were digested with excess (10 units) Hind III for $1 \mathrm{~h}$ at $37^{\circ} \mathrm{C}$. The digest, together with undigested controls, was then electrophoresed on $0.4 \%$ agarose (TBE) at $10 \mathrm{~V}$ overnight or $0.7 \%$ agarose (TBE) at $60 \mathrm{~V}$ for $3 \mathrm{~h}$.

\section{RESULTS}

\section{Purification of CBV}

Although CBV particles were successfully purified from gill tissues, epidermal tissues, head soft tissues, and hemolymph, the cleanest preparations (Figs. 1 \& 2) were obtained from the hemolymph. Furthermore, virus purification from the hemolymph did not require the homogenization step which was necessary for all other tissues. 
A
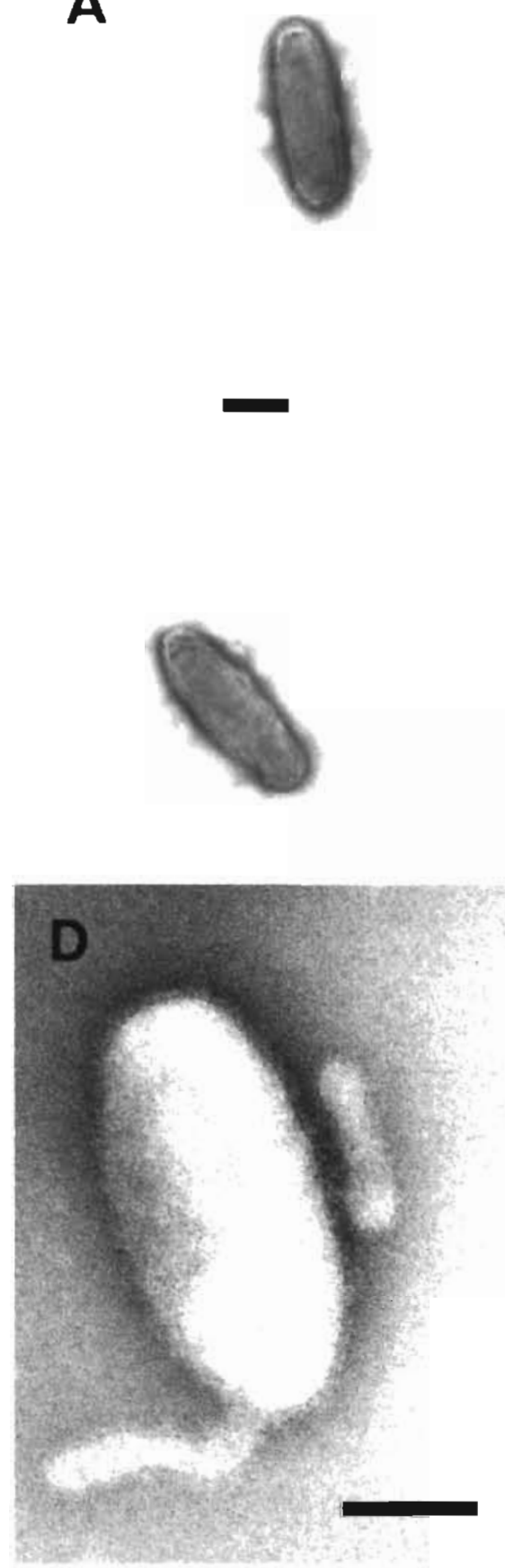
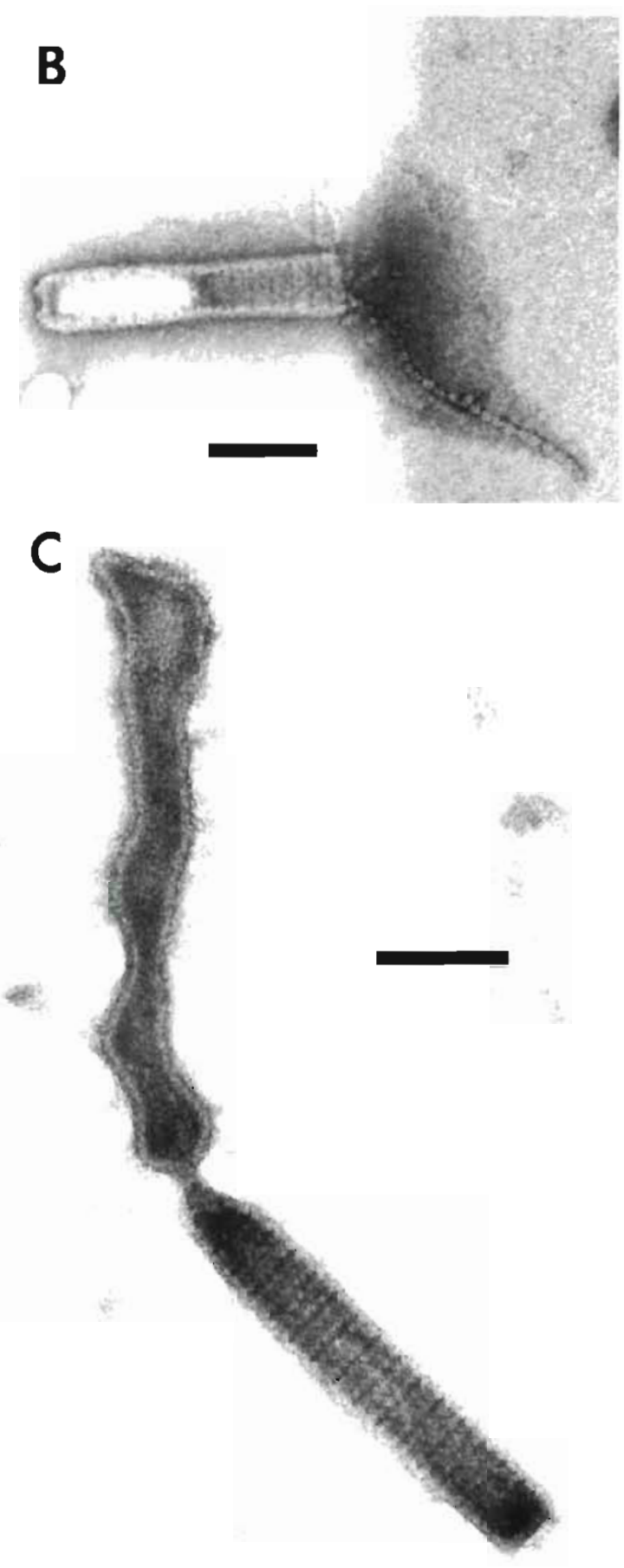

Fig. 1 Electron micrographs of negatively stained CBV particles. (A) Whole virus particles partially penetrated by the stain revealing the nucleocapsid. (B) Partially degraded nucleocapsid with the globular subunits unwound. (C) Virus particle with the outer envelope almost completely removed from the nucleocapsid. (D) Whole virus particle showing a tail-like extension from the outer envelope. All scale bars $=100 \mathrm{~nm}$

Isopycnic centrifugation in $\mathrm{CsCl}$ was found to be superior to sucrose gradients for the optimal purification of CBV particles and nucleoprotein cores. The complete virions banded at $1.22 \mathrm{~g} \mathrm{ml}^{-1}$ and the nucleoprotein cores banded at $1.31 \mathrm{~g} \mathrm{ml}^{-1}$ in CsCl.

\section{Structure of CBV}

Electron microscopical examination of negatively stained complete CBV particles revealed a rod-shaped nucleoprotein core enclosed in a tight-fitting capsid 


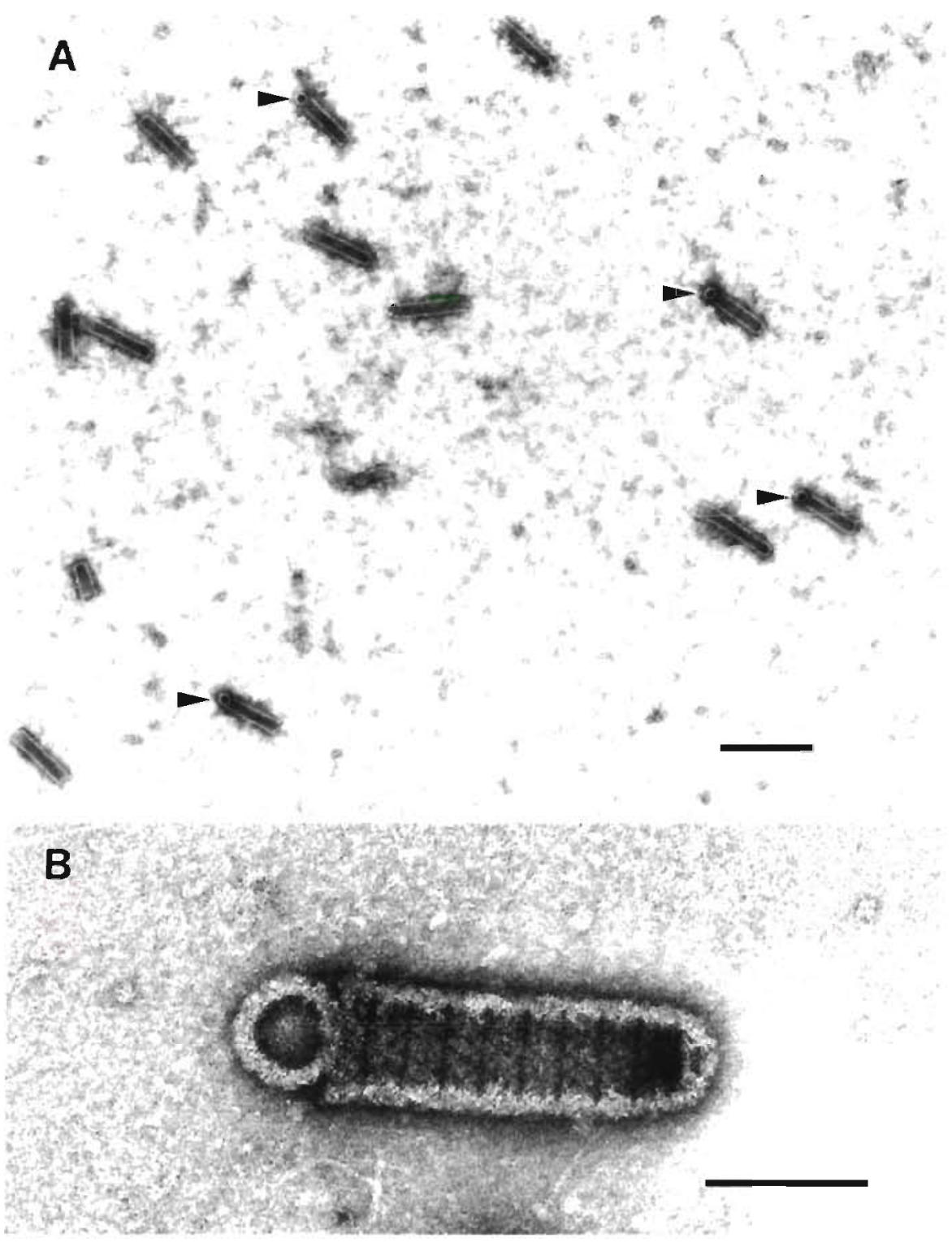

Fig. 2. Electron micrographs of negatively stained $C B V$ nucleoprotein cores. (A) Lower magnification showing ring-like structures (arrowheads) peeling away from several nucleoprotein cores (scale bar = $500 \mathrm{~nm}$ ). (B) Higher magnification showing a close-up view of the ringlike structure still attached to the nucleoprotein core (scale bar = $100 \mathrm{~nm})$

layer and a loose-fitting outer membrane (Fig. 1A, C). Because of the loosely fitting outer membrane, the diameter of the whole virus was as large as 130 to $159 \mathrm{~nm}$ and provided an ellipsoidal shaped structure (Fig. 1A, D) occasionally exhibiting tail-like membranous extensions (Fig. 1D).

Electron microscopical examination of negatively stained nucleoprotein cores revealed some 14 to 15 conspicuous vertical striations located periodically along the long axis of the rod-shaped core and about $22 \mathrm{~nm}$ apart (Fig. 1C). These striations are probably the result of the stacking of ring-like structures making up the nucleoprotein core structure (Fig. 2A, B). These rings consist of 2 rows of 12 to 14 essentially globular structures each approximately $10 \mathrm{~nm}$ in diameter (Fig. 3). Degraded nucleocapsids occasionally exhib- ited globular structures that seem to be attached to each other like beads on a string (Fig. 1B). The total length of the nucleoprotein core is 316 to $350 \mathrm{~nm}$ with a diameter of 65 to $66 \mathrm{~nm}$.

\section{CBV structural proteins}

Analysis of the structural proteins of the virus by SDS-PAGE gel electrophoresis of purified whole virus particles revealed at least 4 prominent and consistent proteins that were approximately 19,23.5, 27.5 and $75 \mathrm{kDa}$ in size (Fig. 4A, lane 1, asterisks). The additional $60 \mathrm{kDa}$ band seen in lane 1 of Fig. 4A was not virus-specific since it was not observed in other purified virus samples (data not shown). A very high mole- 
cular weight band (>200 $\mathrm{kDa}$ ) associated with the nucleoprotein core was also observed (Flg. 4A).

Western blot analysis of complete virions employing polyclonal antibody against CBV revealed the 4 promsnent $(19,23.5,27.5$ and $75 \mathrm{kDa})$ bands but not the high molecular weight band (Fig. 4B). Pre-ımmune rabbit serum did not react with any of these protein bands (data not shown). All 4 protein bands were of virus origin as confirmed by time course in vitro and in vivo virus replication experiments (Nadala et al. 1997).

Fig. 3. Electron micrograph of negatively stained CBV nucleoprotein cores. A computermodified image of the boxed part of the nucleocapsid illustrates the arrangement of the globular subunits. Scale bar = $100 \mathrm{~nm}$

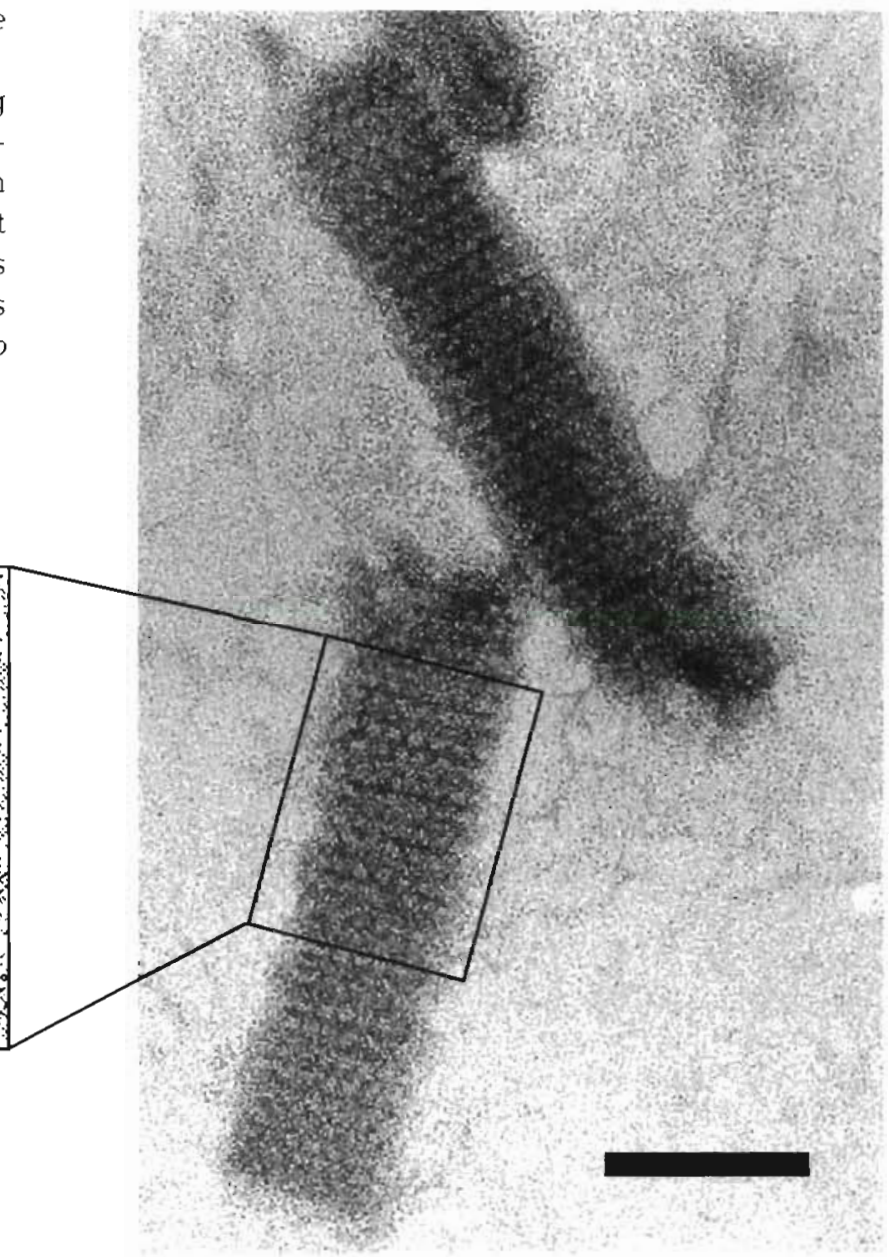

A

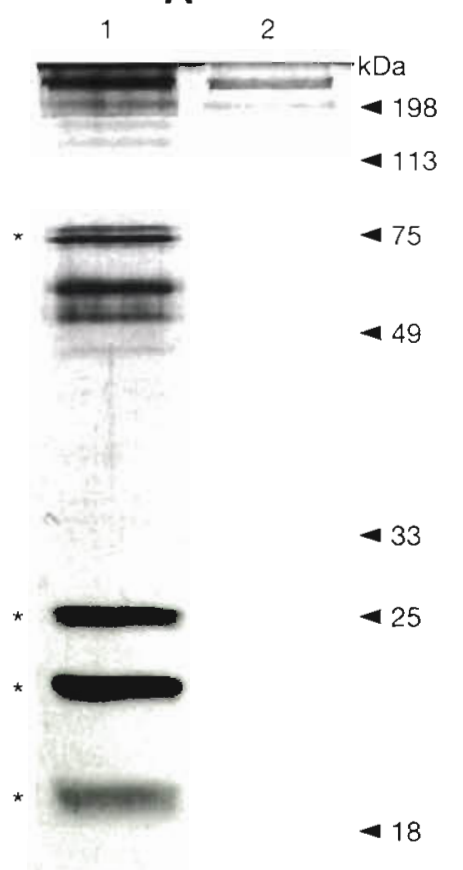

B

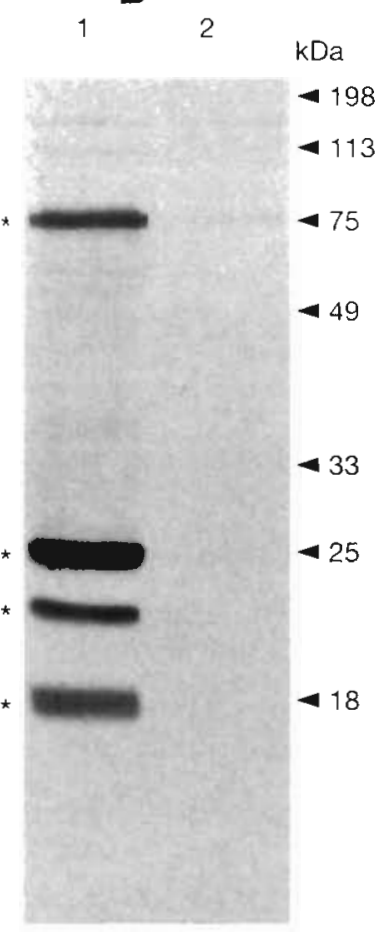

Fig. 4 The structural protens of CBV as revealed by $12.5 \%$ SDS-PAGE gel electrophoresis and western blot. Arrowheads indicate the relative positions of the molecular weight markers Astensks indicate the positions of the 4 prominent structural proteins of CBV (A) Silverstained gel Lane 1: purified whole virus, Lane 2 punfied viral nucleoprotein core. (B) Western blot. Lane 1 purified whole virus; Lane 2: purified viral nucleoprotein core 
SDS-PAGE and western blot analysis of complete virions treated with Triton $\mathrm{X}-100$ showed that the $27.5 \mathrm{kDa}$ protein was easily removed from the virion when the outer lipid membrane was dissolved (Fig. 5A, B). In contrast, the $23.5 \mathrm{kDa}$ protein remained with the nucleoprotein core. However, prolonged treatment with Triton X-100 along with repeated pelleting and resuspension resulted in stripping of the $23.5 \mathrm{kDa}$ protein from the nucleoprotein core (Fig. 4A, B). Although less distinct (the bands are very faint), data in Fig. 5A also suggested that the $19 \mathrm{kDa}$ protein was located in the outer lipid membrane of the virus. Likewise, Fig. 5B suggested that the $75 \mathrm{kDa}$ protein (barely visible in lanes 2 and 5) was also located in the outer lipid membrane.

When purified nucleoprotein core particles were treated with DNAse I (Fig. 6), the very high molecular weight band (lane 1, arrowhead) normally observed even in denaturing SDS-PAGE gels disappeared. However, no new protein bands were detectable after DNAse digestion except for a very low molecular weight band (lane 2, arrowhead) that seemed to migrate with the dye front.

Glycoprotein labelling experiments showed that none of the 4 prominent viral structural proteins were glycosylated (data not shown).

\section{Analysis of the viral nucleic acids}

When purified CBV DNA was digested with Hind III and electrophoresed in an agarose gel $(0.7 \%), 17$ bands were distinguished and reliably sized at $5500,4361,4150,3700,3400,3000$, $2900,2450,2027,1557,1350,1050,970$, $920,740,610$ and 530 bp (Fig. 7). When the same digest was electrophoresed on $0.4 \%$ agarose gel, 12 more bands were easily recognized and reliably sized at $22.8,22,15.2,12.8,12,10.8$, $10.2,8.6,8.4,7.6,7.4$ and $6.9 \mathrm{~kb}$. When combined, a total of 29 fragments were counted with a total size of about $183.9 \mathrm{~kb}$.
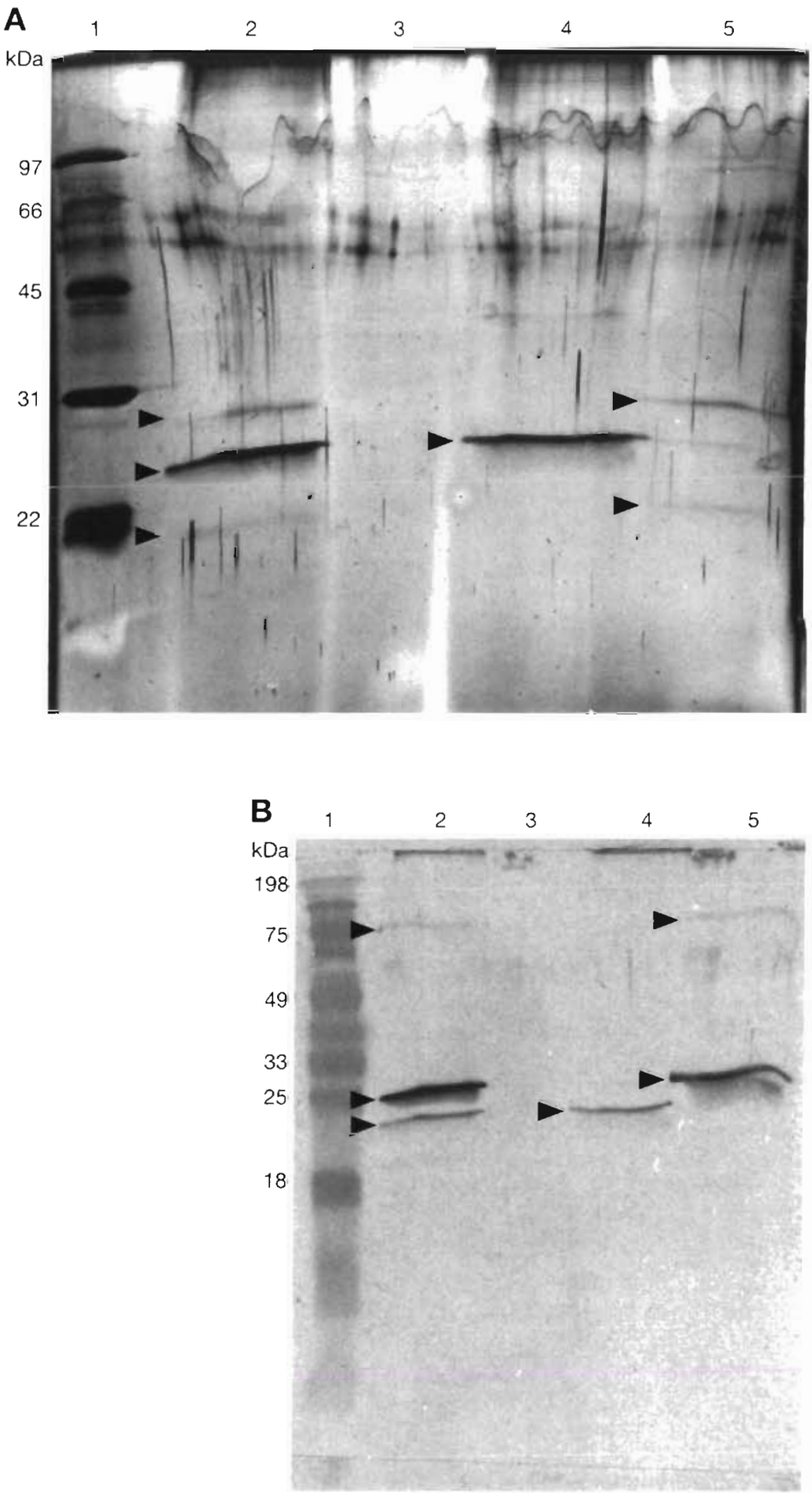

Fig. 5. SDS-PAGE gel electrophoresis and western blot of untreated and Tritontreated CBV. Arrowheads indicate the positions of the protein bands of interest. (A) Silver-stained gel. Lane 1. molecular weight markers; Lane 2: pellet of untreated virus; Lane 3: supernate of untreated virus; Lane 4: pellet of Triton-treated virus; Lane 5: supernate of Triton-treated virus. (B) Western blot. Lane 1: pre-stained molecular weight markers; Lane 2: pellet of untreated virus; Lane 3: supernate of untreated virus; Lane 4: pellet of Triton-treated virus; Lane 5: supernate of Triton-treated virus 


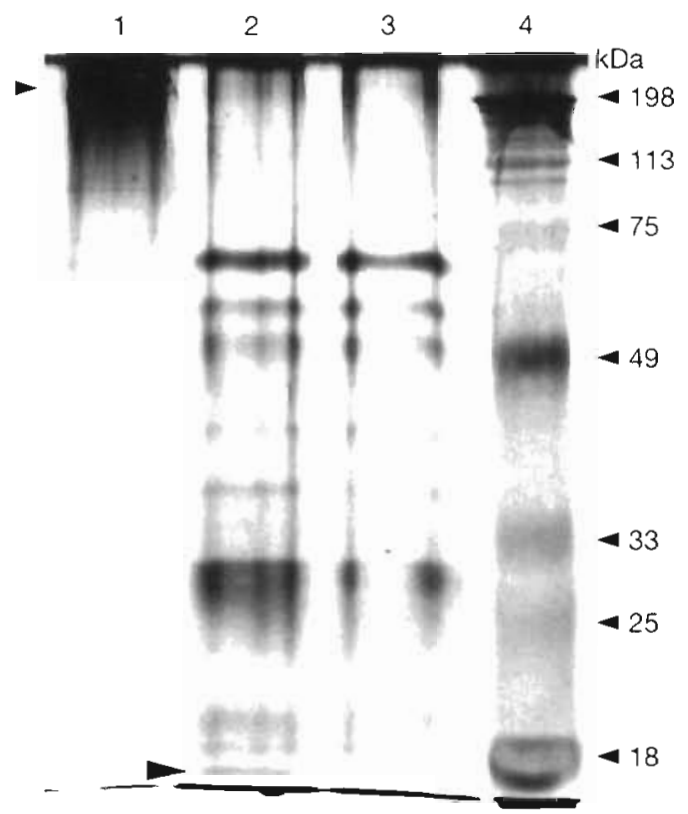

Fig. 6. SDS-PAGE gel electrophoresis of DNAse I treated viral nucleoprotein cores. Silver-stained gel of purified nucleoprotein cores showing the high molecular weight band (arrowhead) in lane 1, DNAse l treated nucleoprotein cores showing the new low molecular weight band (arrowhead) in lane 2. DNAse I alone in lane 3 , and prestained molecular weight markers in lane 4

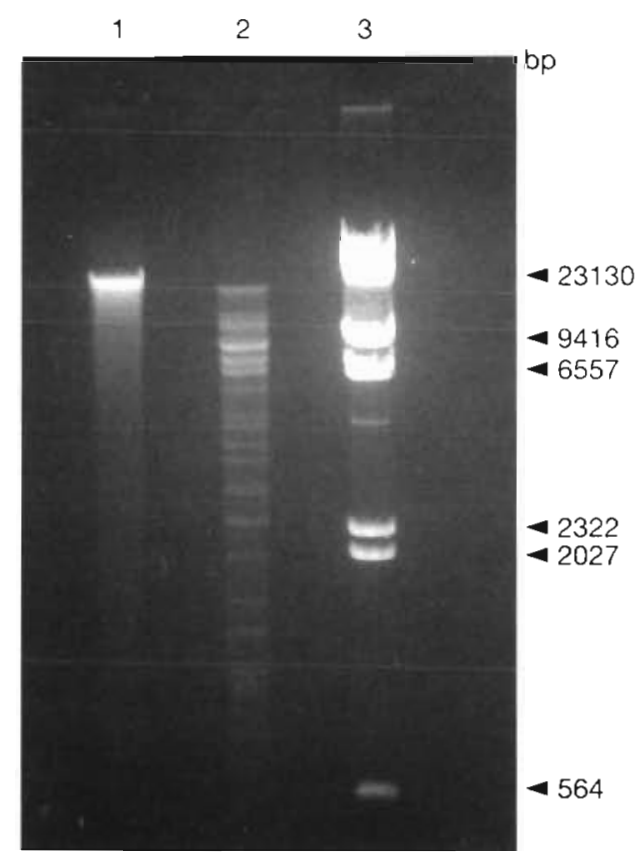

Fig. 7. Agarose gel electrophoresis of purified CBV DNA digested with Hind III. Lane 1: uncut CBV genomic DNA; Lane 2: the CBV genomic DNA digested with Hind III; Lane 3: lambda DNA digested with Hind IIl

\section{DISCUSSION}

The results above suggest that the complete CBV particle consists of a nucleoprotein core, covered with capsid protein, and enveloped in a lipid membrane. The nucleoprotein core is arranged as a series of 14 or 15 stacked rings. It apparently contains the viral DNA and a closely associated low molecular weight protein. The nucleoprotein core has a relatively complex structure and it is likely that there are other proteins that are part of it but have not been clearly demonstrated in our SDS-PAGE gels. These, along with the low molecular weight protein, need to be further characterized.

The nucleoprotein core is covered with a capsid protein of approximately $23.5 \mathrm{kDa}$. The nucleocapsid in turn is enveloped in a lipid membrane containing at least 3 major structural proteins $(19,27.5$, and $75 \mathrm{kDa})$. Based on comparisons between silver-stained gels and their corresponding western blots, the 27.5 and $75 \mathrm{kDa}$ outer membrane proteins seem to be the most immunogenic. However, neither protein was glycosylated. A proposed schematic cutaway diagram of CBV, indicating the tentative locations of the various viral structural proteins and the nucleoprotein core, is shown in Fig. 8.

The protein profile of CBV is unlike that of any known baculovirus. Instead of the 12 to 30 polypeptide species usually seen in SDS-PAGE analyses of baculoviruses (both occluded and non-occluded) (Bilimoria 1986), CBV has 4 prominent structural proteins plus an unknown number of polypeptides present at much lower concentration. This, plus the unique structure of its nucleocapsid, distinguishes $C B V$ from present members of the Baculoviridae family. Although similar to the baculoviruses in size, general structure, and genome composition, CBV along with the former members of the Nudibaculovirinae subfamily await reassignment by the International Committee on Taxonomy of Viruses (Murphy et al. 1995).

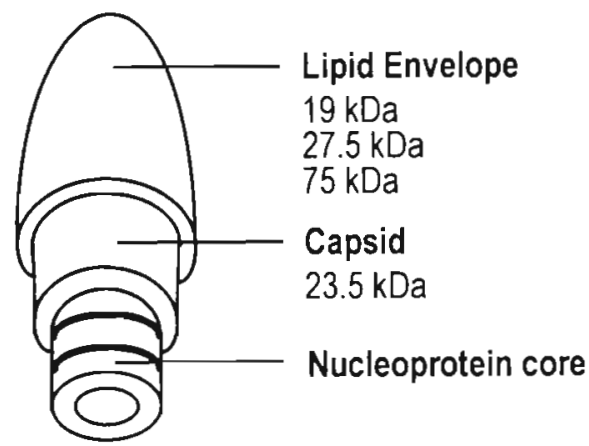

Fig. 8. Proposed schematic cutaway diagram of CBV indicating the tentative locations of the various viral structural proteins 
The CBV isolate in the present study is one of several non-occluded baculovirus-like agents which have been recently reported to infect several species of penaeid shrimp and cause high mortalities in Asia and SE Asia (Inouye et al. 1994, Takahashi et al. 1994, Arimoto et al. 1995, Wang et al. 1995, Wongsteerasupaya et al. 1995). The present isolate shares a unique nucleocapsid morphology (striated structure) with the white spot baculovirus (WSBV) described by Wang et al. (1995), the Penaeus monodon non-occluded baculovirus II (PmNOBII) described by Wongteerasupaya et al. (1995), and the penaeid rod-shaped DNA virus (PRDV) described by Inouye et al. (1996).

The estimated total size of the Hind III-digested fragments of CBV-DNA seemed to be larger than that reported for WSBV $(183.9+\mathrm{kb}$ versus $150+\mathrm{kb})$ by Wang et al. (1995). However, this is probably due to the fact that Wang et al. counted only 22 fragments versus our 29. At least 2 of the higher molecular weight fragments migrated very closely with other fragments and could have been easily missed. In addition, 5 smaller fragments $(530,610,740,920$, and $970 \mathrm{bp})$ were not included. Despite the slight differences in our estimates of the sizes of individual Hind III fragments, the profile is virtually identical. This suggests that the WSBV isolate of Wang et al. (1995) is probably identical to our CBV.

The sizes estimated for PRDV DNA by Inouye et al. (1996) and for PmNOBII DNA by Wongteerasupaya et al. (1995) were 163.2 and $168 \mathrm{~kb}$ respectively. The lower estimate for DNA size compared to CBV-DNA could again be due to these authors' conservative counting of the restriction fragments. Because Wongteerasupaya et al. (1995) did not report the individual sizes of their fragments, it was not possible to make direct comparisons. However, if one compares the profile of the EcoR I restriction fragments of PRDV (Inouye et al. 1996) with that of PmNOBII (Wongteerasupaya et al. 1995), it is apparent that they are also nearly identical. Inouye et al. noted a difference only because Wongteerasupaya et al. had inadvertently transposed the names of the restriction enzymes in their figure (Lo et al. 1996). More recent data reported by Lo et al. (1996) indicate that WSBV ECoR I and BamH I restriction profiles were similar to those of PmNOBII. Since we already have some evidence that WSBV is identical to CBV, this means that PRDV and PmNOBII may be the same virus as well. More restriction endonuclease analyses using a battery of enzymes are needed to confirm this close relatedness or identity among the different isolates.

The size dimensions of the virus particles appeared to vary among the different isolates. However, it is difficult to compare virus dimensions of even negativelystained purified virus samples prepared in different laboratories.
A difference was noted between CBV and the other isolates (PRDV, WSBV, PmNOBII) in the characteristic pathological response of cultured penaeid shrimp. such as Penaeus monodon, P. japonicus, and P. penicillatus when infected with these viruses. Observed in such infected shrimp were a general reddish coloration and the production of conspicuous white spots on the carapace, appendages and inside surface of the body. In contrast, CBV infection of the $2 \mathrm{com}$ mercial species, $P$. stylirostris and $P$. vannamei cultured in Hawaii, does not result in the appearance of white spots. Also, the general reddish coloration is seen only occasionally and primarily in the extremities of the infected shrimp. These differences in responses however, may reflect a difference in the penaeid species involved and/or the fact that $C B \vee$ was inoculated into the shrimps by injection at a high dosage while the other isolates underwent a natural infection.

Lastly it should be noted that the CBV was originally isolated from Penaeus japonicus obtained from a farm in the People's Republic of China. The virus was found to be highly pathogenic for the penaeid species cultured here in Hawaii (Tapay et al. 1997, Lu et al. 1997). Available data indicate that the CBV isolate is probably closely related if not identical to the other isolates associated with the white spot syndrome disease. A recent report employing an in situ DNA hybridization procedure has presented evidence to strongly suggest that these isolates may be closely related variants (Wongteerasupaya et al. 1996). However, a definitive comparison awaits further characterization of these viruses, especially protein profiles, more RFLP (restriction fragment length polymorphism) studies, nucleic acid sequencing, and serologic testing.

Acknowledgements. This study was supported by grants from the University of Hawaii Sea Grant and College Program, Institutional Grant No. NA36RG0507, UNIHI-SEAGRANTJC-98-03, and the Aquaculture Development Program, Department of Land and Natural Resources, State of Hawaii Contract No. 38066.

\section{LITERATURE CITED}

Arimoto M, Yamazaki T, Mizuta Y, Furusawa I (1995) Characterization and partial cloning of the genomic DNA of a baculovirus from Penaeus japonicus ( $\mathrm{PjNOB}=\mathrm{BMNV}$ ). Aquaculture (Amsterdam) 132:213-220

Bilimoria SL (1986) Taxonomy and identification of baculoviruses. In: Granados RR, Federici BA (eds) The biology of baculoviruses, 1 st edn, Vol 1 Biological properties and molecular biology. CRC Press, Boca Raton, p 44-53

Chou HY, Huang CY, Wang CH, Lo CF (1995) Pathogenicity of a baculovirus infection causing white spot syndrome in cultured penaeid shrimp in Taiwan. Dis Aquat Org 23: $165-173$ 
Inouye $\mathrm{K}$, Miwa S, Oseko N, Nakano H, Kimwa T, Momoyama K. Hiraoka M (1994) Mass mortalities of cultured kuruma shrimp, Penaeus japonicus, in Japan in 1993 : electron microscopic evidence of the causative virus. Fish Pathol 29:149-158

Inouye K, Yamano K, Ikeda N, Kimwa T, Nakano H, Momoyama K, Kobayashi J, Mlyajima S (1996) The penaeid rodshaped DNA virus (PRDV), which causes penaeid acute viremia (PAV). Fish Pathol 31:39-45

Laemmli UK (1970) Cleavage of structural protein during the assembly of the head of bacteriophage T4. Nature 227 : $680-685$

Lo CF, Ho CH, Peng SE, Chen CH, Hsu HC, Chiu YL, Chang CF, Liu KF, Su MS, Wang CH, Kou GH (1996) White spot syndrome baculovirus (WSBV) detected in cultured and captured shrimp, crabs and other arthropods. Dis Aquat Org $27: 215-225$

Lu Y, Tapay LM, Loh PC, Gose RB, Brock JA (1997) The pathogenicity of a baculo-like virus isolated from diseased penaeid shrimp obtained from China for cultured penaeid species in Hawaii. Aquacult Int 5:277-282

Murphy FA, Fauquet CM, Bishop DHL, Ghabrial SA, Jarvis AW, Martelli GP, Mayo MA, Summers MD (1995) Virus taxonomy. Archives of virology. Springer-Verlag, Vienna

Nadala ECB Jr, Tapay LM, Cao S, Loh PC (1997) Detection of yellowhead virus and Chinese baculovirus in penaeid shrimp by the western blot technique. J Virol Meth 69 $39-44$

Editorial responsibility: Larry Vaughan,

Dublin, Ireland
Takahashi Y, Itami T, Kondo M, Maeda M, Fujii R, Tomonaga S, Supamattaya K, Boonyaratpalin S (1994) Electron microscopic evidence of bacilliform virus infection in kuruma shrimp (Penaeus japonicus). Fish Pathol 29: $121-125$

Tapay LM, Lu Y, Gose RB, Brock JA, Loh PC (1997) Infection of white-spot baculovirus-like virus (WSBV) in two species of penaeid shrimp, Penaeus stylirostris (Stimpson) and P. vannamei (Boone). In: Flegel TW, MacRae IH (eds) Diseases in Asian aquaculture III. Fish Health Section, Asian Fisheries Society, Manila, p 297-302

Wang CH, Lo CF, Leu JH, Chou CM, Yeh PY, Chou HY, Tung MC, Chang CF, Su MS, Kou GH (1995) Purification and genomic analysis of baculovirus associated with white spot syndrome (WSBV) of Penaeus monodon. Dis Aquat Org 23:239-242

Wongteerasupaya $C$, Vickers JE, Sriurairatana S, Nash GL, Akarajamorn A, Boonsaeng V, Panyim S, Tassanakajon A, Withyachumnarnkul B, Flegel TW (1995) A non-occluded, systemic baculovirus that occurs in cells of ectodermal and mesodermal origin and causes high mortality in the black tiger prawn Penaeus monodon. Dis Aquat Org 21:69-77

Wongteerasupaya C, Wongwisansri S, Boonsaeng V, Panyim S, Pratanpipat P, Nash G, Withyachumnarnkul B, Flegel TW (1996) DNA fragment of Penaeus monodon baculovirus PmNOBII gives positive in situ hybridization with white-spot viral infections in six penaeid shrimp species Aquaculture (Amsterdam) 143:23-32

Submitted: September 27, 1997; Accepted: April 15, 1998 Proofs received from author(s): June 6, 1998 